\title{
PENGARUH BERBAGAI JENIS PENYAMAKAN DAN TIPE FINISH TERHADAP MORFOLOGI, SIFAT ORGANOLEPTIS DAN MEKANIS KULIT BIAWAK (Varanus salvator)
}

\section{INFLUENCE OF VARIOUS TANNING AND FINISH TYPE ON MORPHOLOGY, ORGANOLEPTIC AND MECHANICAL PROPERTIES OF MONITOR LIZARD SKIN (Varanus salvator)}

\author{
Emiliana Kasmudjiastuti*, Sri Sutyasmi, Rihastiwi Setiya Murti \\ Balai Besar Kulit, Karet, dan Plastik, J1. Sokonandi No. 9, Yogyakarta 55166, Indonesia \\ "Penulis korespondensi. Telp.: +62 274 512929, 563939, Fax.: + 62274563655 \\ E-mail: emil_bbkkp@yahoo.com
}

Diterima: 24 Agustus 2015 Direvisi: 9 November 2015 Disetujui: 10 November 2015

\begin{abstract}
Monitor lizard (Varanus salvator) skin is exotic leather because it has a unique grain. Therefore, the original grain of the animal needs to be maintained in the finishing process so that its performances look likes natural. This research aimed to study the effect of tanning materials (vegetable and chrome) and the type of finish (natural, aniline, semi-aniline and two tone) on morphology, organoleptic and mechanical properties of lizard skin. The materials used in this study were dry preserved lizard skins. The research varied on the types of tanning (vegetable and chrome) and the type of finish (natural, aniline, semi-aniline and two tone) each by varying the finishing materials (casein and protein binders). The tests were conducted on the observation of the structure using photomicrographs, rub fastness, adhesion of finish strength, tensile strength, elongation at break and organoleptic. The results showed that the best result was vegetable tanned lizard skin using natural finish with casein and met the requirements of SNI 06-4362-1996, lizard skin for shoe upper. This gave dry and wet rub fastness of 5 and 5 respectively; dry and wet adhesion of finish strength of 650 and $100 \mathrm{~g} / \mathrm{cm}$ respectively; tensile strength of $207.43 \mathrm{~kg} / \mathrm{cm}^{2}$; elongation at break of $37.52 \%$ and organoleptic value of panelists observations of 87.9 (good).
\end{abstract}

Keywords: Monitor lizard (Varanus salvator) skin, tanning, finish type, morphology, organoleptic and mechanical properties.

\begin{abstract}
ABSTRAK
Kulit biawak (Varanus salvator) merupakan kulit exotic karena memiliki rajah yang unik, oleh karena itu dalam proses finishingnya rajah asli dari binatang tersebut perlu dipertahankan agar tampak alami. Penelitian ini bertujuan untuk mengetahui pengaruh jenis bahan penyamak (nabati dan krom) dan tipe finish (natural, anilin, semi anilin, dan two tone) terhadap morfologi, sifat organoleptis dan mekanis kulit biawak. Bahan yang digunakan dalam penelitian ini adalah kulit biawak awet kering dan variasi yang dilakukan meliputi variasi jenis penyamakan (nabati dan krom) dan tipe finish (natural, anilin, semi anilin, dan two tone) dengan penggunaan bahan finishing yang bervariasi (kasein dan binder protein). Uji yang dilakukan meliputi pengamatan struktur menggunakan fotomikrograf, uji ketahanan gosok cat, kekuatan rekat cat tutup, kekuatan tarik, kemuluran, dan organoleptis. Hasil penelitian menunjukkan bahwa hasil yang terbaik adalah kulit biawak yang disamak nabati menggunakan tipe finish natural dengan kasein dan memenuhi persyaratan SNI 06-4362-1996, Kulit biawak untuk atasan sepatu, dengan nilai ketahanan gosok cat kering dan basah berturut-turut 5 dan 5; kekuatan rekat cat tutup kering dan basah berturut-turut 650 dan $100 \mathrm{~g} / \mathrm{cm}$; kekuatan tarik $207,43 \mathrm{~kg} / \mathrm{cm}^{2}$; kemuluran $37,52 \%$; dan nilai organoleptis hasil pengamatan panelis 87,9 (baik).
\end{abstract}

Kata kunci: kulit biawak (Varanus salvator), penyamakan, tipe finish, morfologi, sifat organoleptis dan mekanis.

\section{PENDAHULUAN}

Regulasi perdagangan kulit reptil diatur oleh CITES (Convention on International Trade in Endangered Species of Wild Fauna and Flora) dan
Peraturan Menteri Perdagangan Republik Indonesia Nomor 50/M-DAG/PER/9/2013. Jenis biawak yang dilindungi adalah biawak coklat (Varanus gouldi), biawak maluku (Varanus indicus), biawak 
komodo (Varanus komodoensis), biawak abuabu (Varanus nebulosus), biawak hijau (Varanus prasinus), biawak timor (Varanus timorensis), dan biawak togian (Varanus togianus). Biawak yang tidak dilindungi adalah biawak air tawar (Varanus salvator). Biawak air tawar (Varanus salvator) dimasukkan ke dalam status least concern (LC) / beresiko rendah. Biawak air tawar (Varanus salvator) dimasukkan ke dalam Appendiks II, artinya dapat diperdagangkan. Untuk biawak jenis: Varanus beccari, Varanus doreanus, Varanus dumerili, Varanus jobiensis, Varanus rudicollis, Varanus salvadori, dan Varanus salvator, termasuk satwa liar yang tidak dilindungi undang-undang dan termasuk dalam daftar CITES (Menteri Perdagangan, 2013).

Finishing kulit menggambarkan seluruh rangkaian proses yang dapat meningkatkan beberapa sifat fisika seperti ketahanan kikis, ketahanan terhadap sinar, panas, dan air. Selain itu finishing dapat meningkatkan aspek pewarnaan pada permukaan kulit dan menambah efek modis (Y1lmaz et al., 2011; Fuck et al., 2011) yaitu dengan perlakuan fisis, pemberian bahan kimia/aplikasi larutan pada permukaan kulit yang dilanjutkan dengan perlakuan mekanis sehingga akhirnya kulit berpenampilan menarik dan berkualitas (Fuck et al., 2011). Komposisi bahan finishing umumnya meliputi pigmen, binder, dyes, wax, plasticizer, thickener, filler, penetrator (Niculescu et al., 2012; Gumel \& Dambatta, 2013; Assomac, 2013; Niculescu et al., 2015a) dan emulsi nitroselulosea (Niculescu, et al., 2015b). Binder adalah kompon makromolekul pembentuk film, seperti akrilik, butadiena, poliuretan, dan protein yang berpengaruh terhadap efek kilap, buram serta kekuatan tarik, sobek, kemuluran, cracking, wet and dry friction, bending, light, dan lain-lain (Niculescu et al., 2012). Binder dicampur dengan pigmen dapat memberikan sifat perekat (adhesive properties) pada kulit, sehingga dapat melindungi permukaan kulit terhadap pengaruh luar (Gumel \& Dambatta, 2013). Hampir semua kulit reptil menggunakan cat tutup yang menggunakan binder protein/ kasein, karena dengan menggunakan binder kasein, rajah tampak transparan, lebih indah seperti aslinya (Sumarni dkk., 2013). Kasein merupakan polimer natural, bahan yang mudah terdegradasi, mempunyai sifat perekat yang bagus dan tahan terhadap temperatur tinggi (Jianzhong et al., 2012). Nitroselulosa secara luas digunakan untuk lapisan atas (top coat) karena mudah diaplikasikan tanpa fiksasi dan menghasilkan film yang transparan, tahan terhadap air, mudah dicuci (washable), mudah dibersihkan, menangkis kotoran (dirt repellant), tahan terhadap tekanan mekanis, ketahanan gosok kering dan ketahanan terhadap sinar bagus, ketahanan gosok basah sedang, tetapi ketahanan terhadap panas jelek (Gumel \& Dambatta, 2013).

Umumnya tipe finish dibedakan menjadi 3 yaitu berdasarkan perbedaan permukaan/efek yang dihasilkan (anilin, semi anilin, opaque, antique, transfer, two tone), berdasarkan produk yang digunakan (aqueous casein, aqueous polish, nitroselulosa, poliuretan), dan berdasarkan perlakuan mekanik (glaze, plate, embossed, spray, curtain coating dan roller coating) (BASF, 2009). Penelitian terkait tipe finish yang pernah dilakukan yaitu plate dan non plate dilakukan oleh Susilowati dkk. (2005), tipe finish glossy (glaze) oleh Suryaningsih dkk. (2007) yang diterapkan pada kulit ikan.

Kulit reptil digolongkan dalam kulit non konvensional, memiliki rajah yang khas dan unik dengan motif yang berpigmen berhamburan diseluruh permukaan kulit, sehingga dikenal dengan exotic leather. Bila dijadikan produk akan memberikan nilai jual yang tinggi dibanding kulit konvensional seperti kulit sapi, domba dan kambing. Kulit finish dari kulit biawak maupun ular biasanya digunakan untuk pembuatan tas, dompet, sepatu, ikat pinggang dan lain sebagainya. Umumnya pegangan dan kenampakan kurang natural, oleh karena itu perlu ditingkatkan performance kulit reptil baik dari segi pegangan maupun penampilan agar mempunyai nilai jual yang tinggi.

Tujuan penelitian adalah untuk mengetahui pengaruh jenis bahan penyamak (nabati dan krom) dan tipe finish (natural, anilin, semi anilin, dan two tone) terhadap morfologi, sifat organoleptis dan mekanis kulit biawak.

\section{BAHAN DAN METODE Bahan Penelitian}

Bahan baku yang digunakan dalam penelitian ini adalah kulit biawak (Varanus salvator) mentah awet kering (berasal dari Pekalongan). Bahan penyamak: chromosal $\mathrm{B}$ dan mimosa, bahan penyamak ulang: RS 38, PWB, Tanigan PAK, Novaltan F, RR7, RP2, minyak; Sodoil SPE, minyak sintetis (SAF), Sandolix WWL, bahan pewarna sintetis warna havana dan brown, bahanbahan pembantu untuk penyamakan dan bahanbahan untuk finishing seperti liquid dyes, pigmen, 
binder protein, kasein, RU, RA, minyak kationik, thinner, dan lacquer solvent. Bahan penyamak dan bahan pembantu untuk penyamakan serta bahan untuk finishing berasal dari distributor bahan kimia untuk kulit di Yogyakarta.

\section{Peralatan Penelitian}

Alat untuk proses dan finishing kulit terdiri atas: drum penyamakan, alat pentang, hand staking terbuat dari lempeng baja diameter $20 \mathrm{~cm}$, spray gun, mesin glazing, mesin seterika (plating) merek Mostardini. Alat uji terdiri dari: alat uji crockmeter merek AATCC, model M238 AA, tensile strength tester merek Zwick Roel ZO20 tipe KAP-TC, dan alat uji kekuatan rekat cat tutup (adhesion of finish tester) STD 112, alat pembuatan preparat histologi dan widefield microscope fluorescent in situ hybridization (FISH).

\section{Metode Penelitian}

Kulit biawak sebelum dilakukan finishing terlebih dahulu dilakukan proses penyamakan dengan dua variasi yaitu menggunakan bahan penyamak nabati dan krom. Formulasi penyamakan nabati disajikan pada Tabel 1. Untuk penyamakan krom mulai dari proses perendaman sampai dengan proses pengasaman prosesnya sama seperti pada penyamakan nabati (Tabel 1). Demikian pula pada proses peminyakan dan pewarnaan sampai dengan proses akhir. Proses penyamakan dan proses penyamakan ulang menggunakan bahan penyamak krom disajikan pada Tabel 2.

Tabel 1. Formulasi penyamakan kulit biawak menggunakan bahan penyamak nabati.

\begin{tabular}{|c|c|c|c|c|}
\hline Proses & Bahan kimia/alat & $\%$ & $\mathrm{pH}$ & Durasi waktu (menit) \\
\hline Perendaman & $\begin{array}{l}\text { Air } \\
\text { Tepol/sandosin NIL } \\
\text { Soda abu } \\
\text { Anti kerut (Cismolan UAL) }\end{array}$ & $\begin{array}{r}800 \\
0,5 \\
0,3 \\
0,5\end{array}$ & $9-10$ & $\begin{array}{l}30 \\
30\end{array}$ \\
\hline Pencucian & Air & 300 & & 10 \\
\hline Pengapuran & $\begin{array}{l}\text { Air } \\
\mathrm{Ca}(\mathrm{OH})_{2} \\
\mathrm{Na}_{2} \mathrm{~S}\end{array}$ & $\begin{array}{r}300 \\
5 \\
2\end{array}$ & $11-12$ & \\
\hline $\begin{array}{l}\text { Pencucian } \\
\text { Pembuangan sisik }\end{array}$ & Air & 300 & & 10 \\
\hline $\begin{array}{l}\text { Pencucian } \\
\text { Pembuangan daging } \\
\text { Penimbangan }\end{array}$ & $\begin{array}{l}\text { Air } \\
\text { Pisau seset }\end{array}$ & 300 & & 10 \\
\hline Pembuangan kapur & $\begin{array}{l}\text { Air } \\
\mathrm{ZA} / \mathrm{NH}_{4} \mathrm{Cl}\end{array}$ & $\begin{array}{r}400 \\
1,5\end{array}$ & $7-8$ & \\
\hline Pencucian & Air & 300 & & 10 \\
\hline Pengikisan protein & $\begin{array}{l}\text { Air } \\
\text { Oropon OR }\end{array}$ & $\begin{array}{r}100 \\
0,5-1\end{array}$ & $7-8$ & 45 \\
\hline Penghilangan lemak & Tepol & $0,5-1$ & & 60 \\
\hline Pencucian & Air & 300 & & 10 \\
\hline Pengasaman & $\begin{array}{l}\text { Air } \\
\mathrm{NaCl} \\
\text { FA } \\
\text { Asam sulfat }\end{array}$ & $\begin{array}{r}100 \\
10 \\
0,5 \\
0,5\end{array}$ & $2,5-3$ & \\
\hline Pre tanning & Pamol & 2 & & 30 \\
\hline Penyamakan & $\begin{array}{l}\text { Mimosa } \\
\text { Mimosa } \\
\text { Alum }\end{array}$ & $\begin{array}{l}6 \\
6 \\
2\end{array}$ & & $\begin{array}{c}45 \\
45+180 \\
60\end{array}$ \\
\hline Pencucian & Air & 300 & & 10 \\
\hline Netralisasi & $\begin{array}{l}\text { Air } \\
\text { Sodium bikarbonat }\end{array}$ & $\begin{array}{r}150 \\
1\end{array}$ & & 60 \\
\hline
\end{tabular}


Tabel 1. (lanjutan)

\begin{tabular}{|c|c|c|c|c|}
\hline Proses & Bahan kimia/alat & $\%$ & $\mathrm{pH}$ & Durasi waktu (menit) \\
\hline Pencucian & Air & 300 & & 10 \\
\hline \multirow[t]{4}{*}{ Penyamakan ulang } & Air & 100 & & \\
\hline & PWB & 2 & & 45 \\
\hline & RR7 & 3 & & 45 \\
\hline & Novaltan PF & 3 & & 45 \\
\hline \multirow{10}{*}{$\begin{array}{l}\text { Peminyakan dan } \\
\text { pewarnaan }\end{array}$} & Air & 100 & & \\
\hline & PWB & 3 & & 60 \\
\hline & Levelling agent & 1 & & 10 \\
\hline & Zat warna & 2 & & 60 \\
\hline & Minyak : & & & 60 \\
\hline & - SPE & 2 & & \\
\hline & - LL. SAF & 2 & & \\
\hline & - Sandolix WWL & 2 & & \\
\hline & Asam formiat & 1 & & \\
\hline & Anti jamur & 0,02 & & 30 \\
\hline Pencucian & Air & 300 & & 10 \\
\hline \multicolumn{5}{|l|}{ Penumpukan } \\
\hline \multicolumn{5}{|l|}{ Pelemasan } \\
\hline Pementangan & & & & \\
\hline
\end{tabular}

Formulasi finishing disajikan pada Tabel 3, dengan tujuh variasi, sehingga variabel dalam penelitian ini adalah jenis penyamakan (nabati dan krom) dan tipe finish natural (kasein; binder protein), anilin (kasein; binder protein), semi anilin (liquid dyes; liquid dyes + pigmen), dan two tone $\}$. Kode dalam penelitian ini dapat dilihat pada Tabel 4.

Pengujian yang dilakukan meliputi pengamatan struktur mikro dilakukan dengan alat fotomikrograf, uji ketahanan gosok cat (kering dan ba- sah), kekuatan rekat cat tutup (kering dan basah), kekuatan tarik, kemuluran, dan organoleptis.

Kriteria penilaian uji organoleptis adalah sebagai berikut: kulit dengan pegangan dan penampilan natural, sangat baik: 91-100; kulit dengan pegangan dan penampilan natural, baik: 8190; kulit dengan pegangan dan penampilan natural, cukup: 71-80. Persyaratan mutu mengacu pada SNI 06-4362-1996, Kulit biawak untuk atasan sepatu.

Tabel 2. Formulasi penyamakan dan penyamakan ulang kulit biawak menggunakan bahan penyamak krom.

\begin{tabular}{|c|c|c|c|c|}
\hline Proses & Bahan kimia/alat & $\%$ & $\mathrm{pH}$ & Durasi waktu (menit) \\
\hline \multirow[t]{3}{*}{ Penyamakan } & Air pikel & 80 & & \\
\hline & Chromosal B & 4 & & \\
\hline & $\mathrm{NaHCO}_{3}$ & 1,5 & & $240, \mathrm{ON}$ \\
\hline \multicolumn{5}{|l|}{ Pemeraman } \\
\hline \multirow{2}{*}{ Netralisasi } & Air & 100 & & 60 \\
\hline & Sodium bicarbonat & 1 & & \\
\hline Pencucian & Air & 300 & & 10 \\
\hline \multirow[t]{5}{*}{ Penyamakan ulang I } & Air & 200 & & \\
\hline & RS 38 & 2 & & 45 \\
\hline & PWB & 2 & & 45 \\
\hline & Tanigan PAK & 3 & & 45 \\
\hline & Novaltan PF & 2 & & 45 \\
\hline \multirow[t]{2}{*}{ Penyamakan ulang II } & Tawas/alum & 3 & & 45 \\
\hline & PWB & 2 & & $30+30$ \\
\hline
\end{tabular}


Tabel 3. Formulasi finishing kulit biawak dengan berbagai tipe finish.

\begin{tabular}{|c|c|c|c|}
\hline $\begin{array}{l}\text { Tipe finish } 1 \\
\text { (natural) } \\
\text { Bahan: kras natural }\end{array}$ & $\begin{array}{l}\text { Tipe finish } 2 \\
\text { (anilin) } \\
\text { Bahan: kras warna }\end{array}$ & $\begin{array}{l}\text { Tipe finish 3 } \\
\text { (semi anilim) } \\
\text { Bahan: kras warna }\end{array}$ & $\begin{array}{l}\text { Tipe finish } 4 \\
\text { (two tone) } \\
\text { Bahan: kras warna }\end{array}$ \\
\hline I & $\mathrm{I}$ & I & Lapisan 1 \\
\hline Air: $1000 \mathrm{~g}$ & Air: $1000 \mathrm{~g}$ & Air: $575 \mathrm{~g}$ & Air: $550 \mathrm{~g}$ \\
\hline Kasein : $30 \mathrm{~g}$ & Kasein: $30 \mathrm{~g}$ & Resin uretan: $50 \mathrm{~g}$ & Resin uretan: $50 \mathrm{~g}$ \\
\hline Amonia: $40 \mathrm{~g}$ & Amonia: $40 \mathrm{~g}$ & Resin akrilik: $250 \mathrm{~g}$ & Resin akrilik: $250 \mathrm{~g}$ \\
\hline Minyak kationik: $10 \mathrm{~g}$ & Minyak kationik: $10 \mathrm{~g}$ & $\begin{array}{l}\text { Binder protein: } 75 \\
\text { Liquid dyes: } 50 \mathrm{~g}\end{array}$ & Binder protein : $75 \mathrm{~g}$ \\
\hline Fiksasi: & Fiksasi: & Top coat & Lapisan 2 \\
\hline Formaldehida: $200 \mathrm{~g}$ & Formaldehida: $200 \mathrm{~g}$ & Lak solvent: $200 \mathrm{~g}$ & \multirow{3}{*}{$\begin{array}{l}\text { Air: } 550 \mathrm{~g} \\
\text { Resin uretan: } 50 \mathrm{~g} \\
\text { Resin akrilik: } 250 \mathrm{~g}\end{array}$} \\
\hline Air: $800 \mathrm{~g}$ & Air: $800 \mathrm{~g}$ & Thinner: $800 \mathrm{~g}$ & \\
\hline II & II & II & \\
\hline Air: $750 \mathrm{~g}$ & Air: $750 \mathrm{~g}$ & Air: $575 \mathrm{~g}$ & Binder protein: $75 \mathrm{~g}$ \\
\hline Binder protein: $250 \mathrm{~g}$ & Binder protein: $250 \mathrm{~g}$ & Resin uretan: $50 \mathrm{~g}$ & Liquid dyes: $75 \mathrm{~g}$ \\
\hline Fiksasi & Fiksasi & Resin akrilik:250 g & Top coat \\
\hline Formaldehida: $200 \mathrm{~g}$ & Formaldehida: $200 \mathrm{~g}$ & Binder protein: $75 \mathrm{~g}$ & Lak solvent: $200 \mathrm{~g}$ \\
\hline \multirow[t]{5}{*}{ Air: $800 \mathrm{~g}$} & Air: $800 \mathrm{~g}$ & Liquid dyes: $30 \mathrm{~g}$ & Thinner: $800 \mathrm{~g}$ \\
\hline & & Pigmen: $20 \mathrm{~g}$ & \\
\hline & & Top coat & \\
\hline & & Lak solvent : $200 \mathrm{~g}$ & \\
\hline & & Thinner : $800 \mathrm{~g}$ & \\
\hline Perlakuan mekanis & Perlakuan mekanis & Perlakuan mekanis & Perlakuan mekanis \\
\hline \multirow{3}{*}{$\begin{array}{l}\text { Glazing, plate ringan } \\
\text { (kiss plate) }\end{array}$} & \multirow{3}{*}{$\begin{array}{l}\text { Glazing, plate ringan } \\
\text { (kiss plate) }\end{array}$} & Plating: & Plating: \\
\hline & & Tekanan $50-75$ bar & Tekanan: 50 bar \\
\hline & & $\begin{array}{l}\text { Suhu: } 80^{\circ} \mathrm{C} \\
\text { Waktu: } 2 \text { detik }\end{array}$ & $\begin{array}{l}\text { Suhu: } 80^{\circ} \mathrm{C} \\
\text { Waktu: 1 detik }\end{array}$ \\
\hline
\end{tabular}

Tabel 4. Kode penelitian

\begin{tabular}{cl}
\hline $\begin{array}{c}\text { Kode dalam } \\
\text { penelitian }\end{array}$ & Variabel penelitian \\
\hline A1 & Finish natural - menggunakan kasein (nabati) \\
A2 & Finish natural - menggunakan kasein (krom) \\
B1 & Finish natural - menggunakan binder protein (nabati) \\
B2 & Finish natural - menggunakan binder protein (krom) \\
C1 & Finish semi anilin - menggunakan liquid dyes (nabati) \\
C2 & Finish semi anilin - menggunakan liquid dyes (krom) \\
D1 & Finish semi anilin - menggunakan liquid dyes + pigmen (nabati) \\
D2 & Finish semi anilin - menggunakan liquid dyes + pigmen (krom) \\
E1 & Finish two tone (nabati) \\
E2 & Finish two tone (krom) \\
G1 & Finish anilin - menggunakan binder protein (nabati) \\
G2 & Finish anilin - menggunakan binder protein (krom) \\
H1 & Finish anilin - menggunakan kasein (nabati) \\
H2 & Finish anilin - menggunakan kasein (krom) \\
&
\end{tabular}


HASIL DAN PEMBAHASAN

Analisis Struktur Mikro

Hasil pengamatan struktur mikro menggunakan fotomikrograf dengan perbesaran 100 kali disajikan pada Gambar 1. Secara umum warna untuk kulit biawak samak nabati (A1, B1, C1, D1, E1, G1 dan H1) lebih gelap dibandingkan samak krom (A2, B2, C2, D2, E2, G2, dan H2), hal ini disebabkan karena bahan penyamak nabati bersifat mudah menyerap air dibandingkan samak krom.

Tipe finish natural dan anilin dibanding tipe finish two tone dan semi anilin tampak struktur lebih kompak dan rata sedikit berongga. Hal ini disebabkan karena perlakuan pada tipe finish natural dan anilin dengan cara diulas menggunakan kuas, kemudian di glazed (digosok) dan di plated.
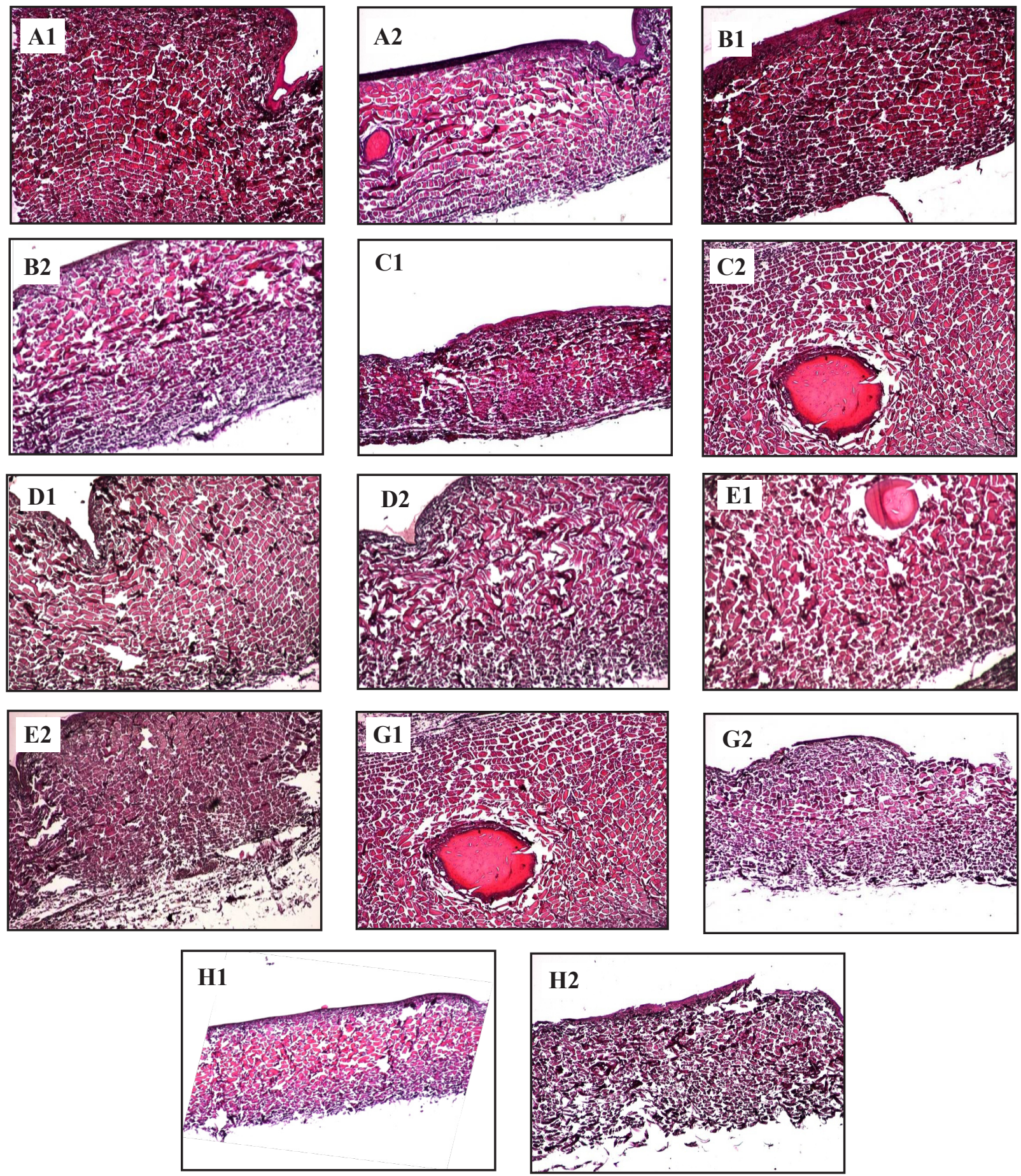

Gambar 1. Fotomikrograf penampang melintang kulit biawak berbagai tipe finish dengan perbesaran $100 \mathrm{X}$. 
Sedangkan perlakuan tipe finish two tone dan semi anilin dengan cara disemprot (spray) kemudian di plated. Tipe finish natural dibandingkan dengan tipe finish anilin struktur kulit tampak lebih kompak, karena pada tipe finish natural tanpa penambahan zat warna dasar, sehingga penyerapan larutan finishing tidak terhalang adanya zat warna dasar. Tipe finish natural menggunakan kasein struktur kulit tampak tidak berbeda dibandingkan dengan menggunakan binder protein, karena keduanya merupakan macromolecular substances yang mengandung albumen/milk.

\section{Pengaruh Tipe Finish terhadap Sifat Orga- noleptis}

Hasil uji organoleptis kulit biawak samak nabati dan krom dengan berbagai tipe finish dapat dilihat pada Gambar 2. Uji organoleptis dimaksudkan untuk mengetahui sejauh mana pegangan dan penampilan yang natural (natural feeling and appearance) terhadap kulit biawak yang di samak nabati atau krom dengan berbagai tipe finish. Pengujian organoleptis dinilai oleh 10 panelis dengan nilai rata-rata seperti ditunjukkan pada Gambar 2. Hasil uji organoleptis tertinggi dicapai oleh kulit biawak baik yang disamak nabati maupun krom dengan tipe finish anilin menggunakan puder kasein ( $\mathrm{H} 1$ dan $\mathrm{H} 2$ ) yaitu dengan nilai ratarata 91,5 (sangat baik: nilai 91-100). Tipe finish lainnya dinilai oleh para panelis dengan nilai rata-rata baik, dengan nilai 81-90. Apabila diamati pada Gambar 2 tampak bahwa hasil uji organoleptis oleh para panelis yaitu pada kulit biawak

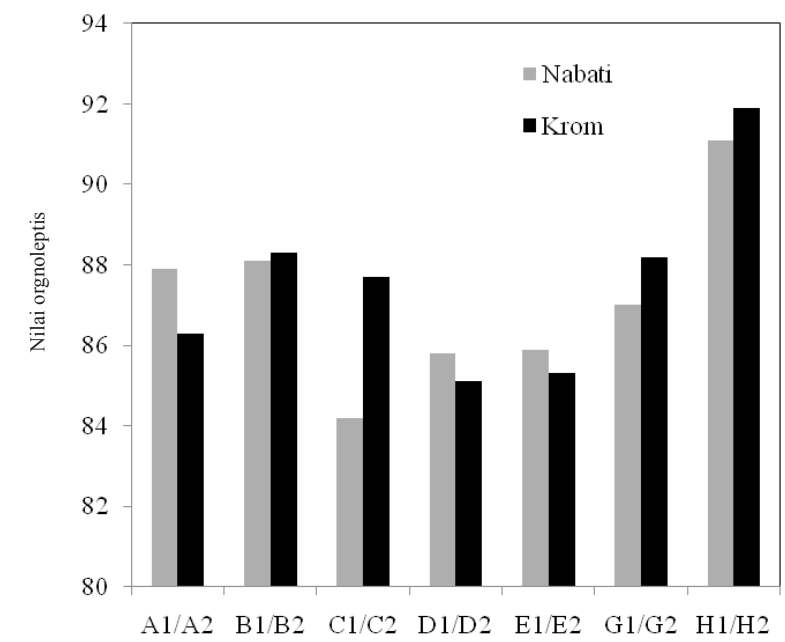

Gambar 2. Grafik histogram hasil uji organoleptis kulit biawak samak nabati dan krom dengan berbagai tipe finish. dengan tipe finish semi anilin menggunakan liquid dyes $(\mathrm{C} 1 / \mathrm{C} 2)$, semi anilin kombinasi liquid dyes dan pigmen (1/D2) dan tipe finish two tone (E1/ E2) lebih rendah dibandingkan menggunakan tipe finish natural dan anilin (A1/A2; B1/B2; G1/G2 dan $\mathrm{H} 1 / \mathrm{H} 2)$. Hal ini disebabkan karena pada tipe finish tersebut digunakan liquid dyes, kombinasi liquid dyes dan pigmen serta top coat menggunakan lak nitroselulosa yang hasilnya lebih kaku dibanding menggunakan kasein atau binder protein. Hasil penelitian ini dibandingkan dengan penelitian sebelumnya yang dilakukan oleh Sumarni dkk. (2013), menunjukkan bahwa penggunaan kasein atau binder protein pada tipe finish natural dan anilin ternyata mampu memberikan pegangan dan penampilan yang natural (natural feeling and appearance). Penampilan yang natural disebabkan karena tipe finish natural dan anilin tanpa penggunaan pewarna, warna yang timbul dari warna asli bahan penyamak (nabati atau krom). Penggunaan kasein atau binder protein memunculkan rajah asli kulit biawak yang tranparan.

\section{Pengaruh Jenis Bahan Penyamak terhadap Kekuatan Tarik}

Kekuatan tarik merupakan salah satu parameter untuk mengetahui kekuatan fisik kulit tersamak. Hasil uji kekuatan tarik kulit biawak samak nabati dan krom dengan berbagai tipe finish dapat dilihat pada Gambar 3.

Pada Gambar 3 dapat dilihat bahwa rata-rata kekuatan tarik kulit biawak samak nabati adalah $301,75 \mathrm{~kg} / \mathrm{cm}^{2}$ dan kulit biawak samak krom

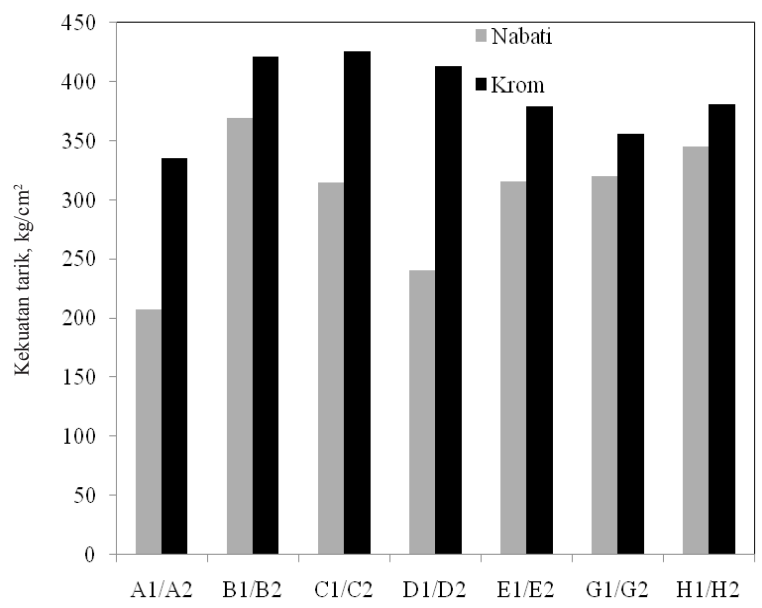

Gambar 3. Grafik histogram kekuatan tarik kulit biawak samak nabati dan krom dengan berbagai tipe finish. 
$387,15 \mathrm{~kg} / \mathrm{cm}^{2}$. Untuk semua perlakuan baik samak nabati maupun krom dengan berbagai tipe finish nilai kekuatan tarik memenuhi persyaratan kulit biawak untuk atasan sepatu yaitu minimal $150 \mathrm{~kg} / \mathrm{cm}^{2}$ (BSN, 1996). Nilai Kekuatan tarik kulit biawak samak krom menunjukkan hasil yang lebih besar dibandingkan kulit biawak samak nabati. Menurut Nashy et al. (2012), kulit samak krom mempunyai sifat kekuatan yang tinggi (high strength properties), better strength and elongation (Nasr et al., 2013; Untari et al., 2005). Nilay et al. (2014) menyatakan bahwa kulit samak krom memberikan hasil uji fisika yang baik dibanding kulit samak nabati. Karakteristik kulit samak krom memiliki lebih banyak ikatan silang antara garam kromium dan serat kolagen dibanding kulit samak nabati (Nasr et al., 2013), sehingga lebih kuat. Rendahnya nilai kekuatan tarik dari kulit samak nabati disebabkan karena bahan penyamak nabati memberikan daya serap air yang tinggi dan mempunyai sifat buffing effect. Buffing effect ialah sifat yang memungkinkan permukaan kulit menjadi keras dan tidak licin (Untari et al., 2005).

\section{Pengaruh Jenis Penyamak terhadap Ke- muluran}

Persentase kemuluran kulit tersamak yang diuji menunjukkan kualitas sifat fisik kulit tersamak. Semakin tinggi persentase kemuluran kulit tersamak, maka kulit akan semakin lemas. Tetapi apabila kulit tersamak keras dan kaku maka persentase kemulurannya akan rendah. Hasil pengujian kemuluran kulit biawak samak nabati dan krom dengan berbagai tipe finish dapat dilihat pada Gambar 4.

Pada Gambar 4 dapat dilihat bahwa ratarata nilai kemuluran kulit biawak samak nabati adalah 52,88\% dan kulit biawak samak krom $60,43 \%$. Untuk semua perlakuan baik samak nabati maupun krom dengan berbagai tipe finish nilai kemuluran memenuhi persyaratan kulit biawak untuk atasan sepatu yaitu maksimum $70 \%$ (BSN, 1996). Nilai kemuluran kulit biawak samak krom menunjukkan nilai yang lebih besar dibandingkan kulit biawak samak nabati. Kulit samak krom mempunyai kualitas yang tinggi seperti kekuatan tarik, kekuatan sobek, dan kemuluran karena mempunyai lebih banyak ikatan silang antara garam kromium dan serat kolagen dibanding kulit samak nabati (Nasr et al., 2013). Untari dkk. (2005) menyatakan bahwa kulit samak krom menghasilkan kemuluran yang tinggi karena kulit

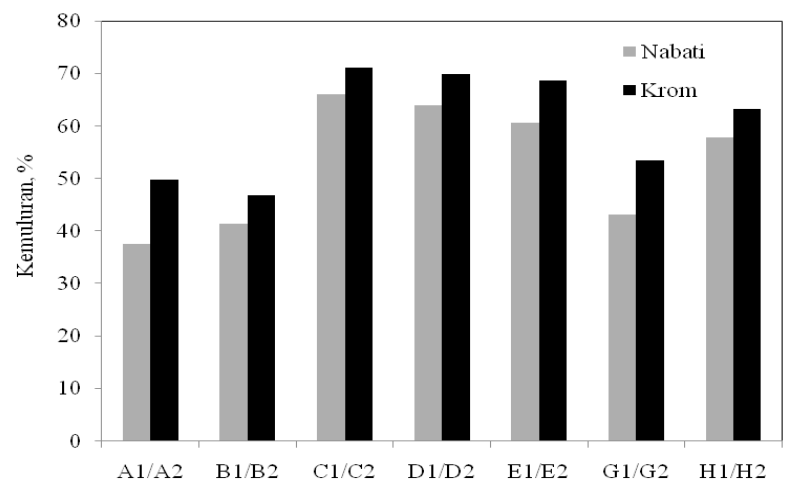

Gambar 4. Grafik histogram kemuluran kulit biawak samak nabati dan krom dengan berbagai tipe finish.

samak krom lebih elastis dibanding kulit samak nabati. Bahan penyamak nabati menyebabkan terjadinya rongga-rongga kosong pada struktur kulit samak karena bahan penyamak nabati tidak terserap seluruhnya ke dalam jaringan kulit. Hal ini dipengaruhi oleh besarnya molekul bahan penyamak nabati sehingga terbentuk endapan dalam larutan. Akibatnya penetrasi bahan penyamak ke dalam jaringan kulit tidak sempurna dan terbentuk rongga-rongga kosong yang mengakibatkan kemulurannya akan rendah. Kulit yang disamak krom lebih mulur dibanding dengan kulit yang disamak nabati (Mustakim dkk., 2010)

\section{Pengaruh Tipe Finish terhadap Ketahanan Gosok Cat}

Ketahanan gosok cat kulit merupakan uji fisika untuk menentukan sifat ketahanan warna (kelunturan warna) produk kulit. Sifat fisika tersebut sangat penting pada performance kualitas dan kepuasan konsumen. Untuk alasan ini, maka uji ketahanan gosok/kelunturan warna akan memiliki efek pada kenyamanan pakai dan kepuasan konsumen terhadap suatu produk (Nilay et al., 2014).

Hasil uji ketahanan gosok cat dengan kain kering dan basah dengan skala abu-abu pada kulit biawak samak nabati dan krom dengan berbagai tipe finish, disajikan pada Tabel 5. Pada Tabel 5 dapat dilihat bahwa umumnya ketahanan gosok cat kering lebih baik dibandingkan ketahanan gosok basah baik untuk samak krom maupun samak nabati. Semua perlakuan A1, A2, B1, B2, C1, C2, D1, D2, E1, E2, G1, G2, H1, dan H2 memenuhi persyaratan SNI 06-4362-1996, Kulit biawak untuk atasan sepatu yang mempersyaratkan minimum 4/5. Demikian pula untuk ketahanan gosok cat basah se- 
Tabel 5. Nilai skala abu-abu (grey scale) kulit biawak samak nabati dan krom dengan berbagai tipe finish.

\begin{tabular}{llcc}
\hline \multirow{2}{*}{ No. } & Kode & \multicolumn{2}{c}{ Ketahanan gosok cat } \\
\cline { 3 - 4 } & & Kering & Basah \\
\hline 1. & A1/A2 & $5 ; 5$ & $5 ; 5$ \\
2. & B1/B2 & $5 ; 4 / 5$ & $4 / 5 ; 4 / 5$ \\
3. & C1/C2 & $4 / 5 ; 5$ & $4 / 5 ; 4 / 5$ \\
4. & D1/D2 & $4 / 5 ; 4 / 5$ & $4 / 5 ; 4 / 5$ \\
5. & E1/E2 & $4 / 5 ; 4 / 5$ & $4 / 5 ; 4 / 5$ \\
6. & G1/G2 & $4 / 5 ; 4 / 5$ & $4 ; 4$ \\
7. & H1/H2 & $5 ; 4 / 5$ & $4 ; 4$ \\
\hline
\end{tabular}

mua perlakuan A1, A2, B1, B2, C1, C2, D1, D2, E1, E2, G1, G2, H1, dan H2, baik samak krom maupun samak nabati yaitu minimum $3 / 4$, bahkan nilainya di atas persyaratan. Hal ini menunjukkan bahwa daya perekat dari binder (kasein dan protein) maupun emulsi lak solvent sebagai lapisan atas cukup kuat merekat pada permukaan kulit. Pelapisan atas (top coat) bertujuan untuk meningkatkan ketahanan gosok dan memberikan efek kilap pada kulit jadinya (Sumarni dkk., 2013). Menurut Lanxees (2011), coating (pelapisan) merupakan tahapan penting pada proses finishing kulit yang berfungsi untuk melindungi permukaan kulit dari pengaruh luar. Setelah perlakuan coating selanjutnya disempurnakan/dimatangkan pada perlakuan plating dengan tekanan, suhu dan waktu tertentu. Perlakuan plating membantu meratakan lapisan yang terbentuk sehingga lapisan menjadi kompak dan permanen, dan secara umum ketahanan terhadap warna meningkat (Kasmudjiastuti, 2014), sehingga dengan perlakuan gosokan menggunakan kain kering maupun basah, warna tidak luntur. Dari Tabel 5 menunjukkan bahwa ketahanan gosok cat terbaik adalah perlakuan cat tutup menggunakan kasein baik samak nabati maupun samak krom (A1/A2) yaitu dengan nilai 5 (kering dan basah). Hal ini sesuai dengan pernyataan Jianzhong et al. (2012), bahwa kasein merupakan polimer natural yang mempunyai sifat perekat yang bagus dan tahan terhadap temperatur tinggi sehingga bila diperlakukan dengan gosokan menggunakan kain kering maupun basah warna tidak luntur.

\section{Pengaruh Tipe Finish terhadap Kekuatan Rekat Cat Tutup}

Perekatan (adhesive) didefinisikan sebagai derajad pengikatan (binding) pada permukaan kulit dari lapisan - lapisan finishing permukaan kulit yang digunakan untuk meningkatkan karakteristik sifat fisis kulit. Lapisan finishing harus merekat kuat pada permukaan kulit. Hasil uji kekuatan rekat cat tutup kulit biawak samak nabati dan krom dengan berbagai tipe finish dapat dilihat pada Gambar 5.

Komposisi bahan finishing terdiri dari pigmen, perekat (binder), pelunak, pelarut, pengisi dan bahan tambahan lainnya. Meskipun bahanbahan tersebut merupakan bahan kimia, namun bahan-bahan tersebut tidak berikatan/bereaksi dengan kulit secara kimia, tetapi hanya merupakan daya adhesif (adhesive power) yaitu gaya tarik menarik antar molekul pada binder dan permukaan kulit sehingga terjadi ikatan yang sangat kuat (Sumarni dkk., 2013). Pada Gambar 5 dapat dilihat bahwa kekuatan rekat cat tutup (kering) untuk semua perlakuan (samak nabati dan krom) dengan berbagai tipe finish memenuhi persyaratan SNI 06-4900-1998, yaitu lebih besar dari $200 \mathrm{~g} /$ $\mathrm{cm}$ (minimum $200 \mathrm{~g} / \mathrm{cm}$ ). Rata-rata kekuatan rekat cat tutup (kering) samak nabati adalah 518,45 $\mathrm{g} / \mathrm{cm}$ dan samak krom $523,21 \mathrm{~g} / \mathrm{cm}$. Rata-rata kekuatan rekat cat tutup (basah) samak nabati adalah 116,07 g/cm dan samak krom 167,26 g/ $\mathrm{cm}$. Untuk kekuatan rekat cat tutup secara basah, nilai yang baik dicapai oleh kulit biawak dengan tipe finish semi anilin menggunakan liquid dyes, kombinasi liquid dyes dan pigmen, dan two tone, baik samak nabati maupun krom yaitu diatas persyaratan SNI 06-4900-1998 (minimum $100 \mathrm{~g} /$ $\mathrm{cm}$ ). Ketiga jenis tipe finish tersebut diberi lapisan atas (top coat) menggunakan lak nitroselulosa, ke-

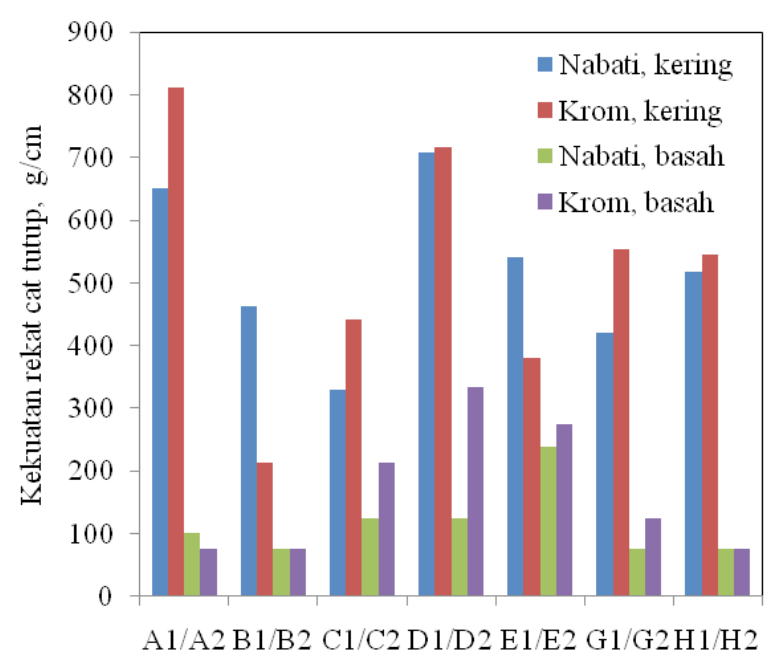

Gambar 5. Grafik histogram kekuatan rekat cat tutup (kering dan basah) kulit biawak samak nabati dan krom dengan berbagai tipe finish. 
mudian dilakukan penyetrikaan/plating, dengan kondisi operasi tekanan $50-75$ bar, suhu $80^{\circ} \mathrm{C}$, waktu 2 detik. Perlakuan plating membantu meratakan lapisan yang terbentuk dan lapisan yang terbentuk menjadi kompak dan permanen (Kasmudjiastuti, 2014), sehingga lapisan yang terbentuk merekat kuat. Berbeda dengan kulit biawak yang difinish menggunakan kasein atau binder protein baik yang disamak nabati maupun krom, mempunyai nilai kekuatan rekat yang rendah $<100 \mathrm{~g} /$ $\mathrm{cm}$ (dibawah persyaratan SNI), kecuali untuk tipe finish natural menggunakan kasein puder samak nabati (A1) dan tipe finish anilin menggunakan binder protein samak krom (G2). Hal ini bertentangan dengan pendapat Jianzhong et al. (2012), bahwa kasein merupakan polimer natural yang mempunyai daya rekat yang bagus. Rendahnya kekuatan rekat cat tutup secara basah ini mungkin disebabkan karena kondisi operasional pada saat plating (suhu, tekanan dan waktu) belum optimal sehingga kekuatan rekatnya rendah. Kulit biawak yang di finish menggunakan kasein dan binder protein, perlakuan mekanik menggunakan alat glazing kemudian disempurnakan dengan penyetrikaan ringan (kiss plate: tekanan 50 - 75 bar, suhu $80^{\circ} \mathrm{C}$, waktu 0 detik).

\section{KESIMPULAN}

Dari hasil penelitian dapat disimpulkan bahwa perlakuan yang terbaik adalah kulit biawak yang di samak menggunakan bahan penyamak nabati dengan tipe finish natural menggunakan kasein dengan nilai ketahanan gosok cat kering $=5$, basah $=5$; kekuatan rekat cat tutup kering dan basah berturut-turut 650 dan $100 \mathrm{~g} / \mathrm{cm}$; kekuatan tarik 207,43 kg/ $\mathrm{cm}^{2}$; kemuluran 37,52\%; nilai organoleptis $=87,9$ (baik) dan memenuhi persyaratan SNI 06-4362-1996, Kulit biawak untuk atasan sepatu.

\section{UCAPAN TERIMA KASIH}

Penulis mengucapkan terima kasih kepada Ibu Niken Karsiati yang telah memberikan bimbingan dan arahan pada penelitian ini, serta kepada Bapak Heru Budi Susanto, Thomas Tukirin, Nurwachid dan Prayitno yang telah membantu dalam penelitian ini.

\section{DAFTAR PUSTAKA}

Assomac. (2013). Italian high technology of tanning

(2nd ed.). Vigevano, Italy: Assomac.
BASF. (2009). Leather Finishing Manual. Ludwigshafen, Germany: BASF.

BSN (Badan Standardisasi Nasional). (1996). Standar Nasional Indonesia SNI 06-4362-1996, Kulit biawak untuk atasan sepatu. Jakarta, Indonesia: BSN.

Fuck, W. F., Gutterres, M., Marcilio, N. R., \& Bordingnon, S. (2011). The influence of chromium supplied by tanning and wet finishing processes on the formation of $\mathrm{Cr}$ (VI) in leather. Brazilian Journal of Chemical Engineering, 28(2), 221228.

Gumel, S. M., \& Dambatta, B. B. (2013). Application and evaluation of the performance of poly(vinyl alcohol) and its blend with nitrocelulose in leather top coating. International Journal of Chemical Engineering and Applications, 4(4), 249-253.

Jianzhong, M., Qunna, X., Zhou, J., \& Wang, Y. (2012). Preparation of casein based silica nano-composite leather finishing agent via double-in-situ emulsion polymerization. In The $9^{\text {th }}$ Asian International Conference on Leather Science and Technology. Taipei, Taiwan: TILA.

Kasmudjiastuti, E. (2014). Optimasi proses finishing kulit ikan nila (Oreochromis niloticus) untuk bagian atas sepatu. Majalah Kulit, Karet, dan Plastik, (30)2, 107-114.

Lanxees. (2011). Launch water based transfer coating. Germany: Lanxees.

Menteri Perdagangan RI. (2013). Peraturan Menteri Perdagangan Republik Indonesia No. 50/M-DAG/ PER/9/2013 tentang ketentuan ekspor tumbuhan alam dan satwa liar yang tidak dilindungi undangundang dan termasuk dalam daftar CITES. Jakarta, Indonesia.

Mustakim, M., Aris, S. W., \& Kurniawan, A. P. (2010). Perbedaan kualitas kulit kambing peranakan etawa (PE) dan peranakan boor (PB) yang disamak krom. Jurnal Ternak Tropika, 11(1), 38-50.

Nashy, E. H., Osman, O., Mahmoud, A. A., \& Ibrahim, M. (2012). Molecular spectroscopic study for suggested mechanism of chrome tanned leather. Spectrochimica Acta Part A: Molecular and Biomolecular Spectroscopy, 88, 171-176.

Nasr, A. I., Abdelsalam, M. M., \& Azzam, A. H. (2013). Effect of tanning methode and region on physical and chemical properties of barki sheep leather. Egyptian Journal of Sheep and Goat Science, 8, 123-130.

Niculescu, O., Leca, M., Coara, G., Macovescu, G., \& Chelaru, C. (2012). Characterization of coating aqueous disperse systems used in natural leather finishing. Chemistry Magazine, Bucharest, 9, 900.

Niculescu, O., Leca, M., Chelaru, C., \& Dinca, L. C. (2015a). Absorption and water resistance of natural leathers finished with ecological touch 
emulsion in the final dressing. Revista de Chimie, 66(1), 124-128.

Niculescu, O., Moldovan, Z., Leca, M., Chelaru, C., Alexandrescu, L., \& Aboul-Enein, H.Y. (2015b). Characteristics of natural leather finished with some ecofriendly mixtures of polymeric aqueous dispersions. Journal of Polymer Engineering, 35(5), 463-470.

Nilay, O. R. K., Hasan, O., Mehmet, M. M., \& Ziynet, O. (2014). Comparative determination of physical and fastness properties of garment leathers tanned with various tanning material for leather skirt production. Tekstil ve Konfeksiyon, 24(4), 413419.

Sumarni, S., Triatmojo, S., \& Nurliyani. (2013). Pengaruh penggunaan binder alami pada proses finishing kulit cakar ayam tersamak terhadap keuatan sobek dan ketahanan gosok cat. Buletin Peternakan, 37(1), 41-48.

Suryaningsih, P. E., Heryanto, Mursulasmo, \& Nainggolan, K. (2007). Pembuatan Kulit Jadi dengan Berbagai Type Finish untuk Atasan Sepatu. Yogyakarta, Indonesia: BBKKP.
Susilowati, Widari, Nainggolan, \& Tukirin, T. (2005). Teknologi pembuatan sepatu dan barang kulit dari kulit ikan (kakap dan kerapu). Yogyakarta, Indonesia: BBKKP.

Untari, S., Jayusman, \& Nainggolan. (2005). Berbagai macam bahan penyamak (mineral, nabati dan Sintetis) untuk penyamakan kulit skrotum domba. Yogyakarta, Indonesia: BBKKP.

Yılmaz, O., Cheaburu, C. N., Gülümser, G., \& Vasile, C. (2011). Rheological behaviour of acrylate/ montmorillonite nanocomposite latexes and their application in leather finishing as binders. Progress in Organic Coatings, 70(1), 52-58. 
